Research Article

\title{
Multi Perception Analysis of Medan City Residents Against the River Environment
}

\author{
Indriyani Rachman ${ }^{1,2}$, Ira Rumiris Hutagalung3, Toru Matsumoto'
}

${ }^{1}$ Graduate Programs in Environmental Systems, Graduate School of Environmental Engineering, The University of Kitakyushu, Japan 808-0135

${ }^{2}$ Department of Natural Science Education, School of Postgraduate Studies, Universitas Pakuan, Indonesia 16143

3Faculty of engineering, Universitas Islam Syekh Yusuf Tangerang

Correspondence email: r-indriyani@kitakyu-u.ac.jp

(c) (i) (2)

\begin{abstract}
Deli Medan River is one of the rivers used as a mode of transportation in the 1980s. The shift in water transportation to land causes the Deli Medan River not to get attention and tend to be ignored. This study aims to describe the perception of the people of Medan City on the Deli River Medan while at the same time looking for a correlation between each variable. This study involved 365 respondents divided from various urban villages in the Medan City area (136 men and 232 girls). The selected respondents are aged 9-6o years with a vulnerable elementary school to a college education. Spearman correlation analysis is used to see the relationship between variables. The results of the study inform that there is no relationship between pollution and siltation that occurs in the Deli River Medan, different results are shown between the changing of river transportation modes to land caused by river silting, the level of education and awareness in disposing of waste, as well as pollution that occurs and industries that dispose of waste. Wastewater in the Medan Deli River body (Sig. <0.05). Furthermore, the Deli Medan River has been polluting by waste and wastewater.
\end{abstract}

Keywords: Deli Medan River; perception; wastewater; water pollution

\section{Introduction}

Deli Medan River is one of the rivers in Medan City and has much historical value (Suprayitno et al., 2020). The Deli River in Medan was formerly used as a transportation medium for the community and the plantation industry (Airriess, 1995). Along with the times and the development of land transportation modes carried out by the Government, the function of the Medan Deli River is slowly being forgotten. The construction of the railway in the 1980s has shifted the river operation as a transportation medium (Suprayitno et al., 2020). Not infrequently, based on the early observation, the younger generation does not know the Deli Medan River's location in detail. Some people do not even know and doubt the Deli Medan River's upstream and downstream regions. The low awareness and knowledge of the community regarding the Deli Medan River show a low level of concern for the existence and sustainability of the river (Zulfa et al., 2018). This phenomenon will be hazardous because low awareness and knowledge of the river will cause river management that is not optimal. This is not 
impossible to trigger various natural disasters such as floods, loss of aquatic biota, and damage to ecosystems along the Deli River, Medan to high sedimentation and erosion (Purba et al., 2013).

Studies on people's perceptions of the existence of the Deli River in Medan are still rarely found. Limited study found through the scholar google search engine for keywords community perceptions of the Medan Deli River, based on the scholar google engine. There were only two pieces of research about community perception in the Deli Medan River (Aulia et al., 2018; Rachman et al., 2021). Other articles found with similar keywords only discussed water quality (Yusni and Melati, 2020), sanitation (Susanti, 2018a), flood ( Siregar et al., 2019), and erosion disaster mitigation (Fadlan et al., 2021). This research is essential to open insight and spark concern for the existence of the Deli River Medan. The preliminary study informed that the community did not care about the presence of the Deli River in Medan because they felt that it was minimally beneficial. The common concern for the Deli River Medan causes the prevention of pollution that occurs in the Deli River Medan to be less than optimal. Various studies have reported the presence of pollutant parameters in the Deli River Medan; even heavy metal content has been found in mangrove plants (Avicennia marina and Rhizophora mucranata) around the Deli River Medan. (Yunasfi et al., 2019). Even a study reported a culture of disposing of sewage and household waste in the Medan Deli River body. This study informed that the community uses the river for several activities such as bathing, washing, defecating, and disposing of human waste and household waste (Zulfa et al., 2018)

Various engineering efforts have been undertaken to minimize and reduce pollution in the Deli River Medan, but multiple actions have not given maximum results. This suboptimal result is caused by people who still throw garbage, dirt, waste, and other activities that can reduce the quality and quantity of the Deli Medan River. Public perception is one of the efforts that can be done to reduce the level of pollution, awareness of the importance of maintaining the sustainability of the Deli Medan River is an effort that can restore the function of the river as it should be. This research is essential to provide an overview of how the people of Medan City view the Medan Deli River and how the opinions and views of the Medan City community regarding actions that can reduce the water quality of the Medan Deli River. The decreasing of the Deli Medan River reported an impact on many diseases to the community around the riverbanks. Recorded cases of diarrhea around the Deli River Medan reached 22,932 points in 2015; diarrhea cases were also recorded to continue to increase to reach 25,575 cases (Susanti, 2018b). This study is expected to provide an overview of the public's perception of the existence of the Deli Medan River, and this study will also look for the relationship between pollution levels and the silting of the Deli Medan River, ship transportation and silting, and Level of Education and Awareness of Disposing of Waste. This study also informs various pollutant parameters, including physical and chemical characteristics.s

\section{Method \\ 2.1 Respondent}

The volunteer in this research is 365 people who lived in Medan City using random sampling (136 men and 232 girls). The age of volunteers in this study is between 9-6o years old, including men and women. Levels of respondent's education have been classifying into five ranks (primary school, junior high school, senior high school, bachelor and master/doctoral degree)

The analysis of resident's perceptions was analyzed by descriptive. This analysis was used to describe the perception of respondents using a pie diagram with the presentation. Three hundred sixtyfive volunteers in this study have been classified into different questions and represented, respectively. 


\subsection{Statistical Analysis}

The Spearman correlation was used to find the correlation between pollution levels and the silting of the Deli Medan River, ship transportation and silting, and Level of Education and Awareness of Disposing of Waste. Each variable has been classifying into five ranks (strongly agree is five, agree is four, doubtful is three, disagree is two, and strongly disagree is one). IBM SPSS Software analyzed the spearman correlation.

\section{Result and Discussion}

\subsection{Respondents Characteristics}

Respondents in this study amounted to 365 people, with a comparison of 136 men and 232 women. The age of the respondents ranged from 9-125 years. The age of the respondents was chosen because they were considered to have good memory and argumentation in providing answers to each question made. The age analysis of respondents was grouped by age 9-20, 21-40, 40-60, and above 60 years to facilitate research on the percentage of respondents' age. Based on the analysis results, it is known that the majority of respondents are $40-60$ years old (36\%) and $21-40$ years old (35\%).

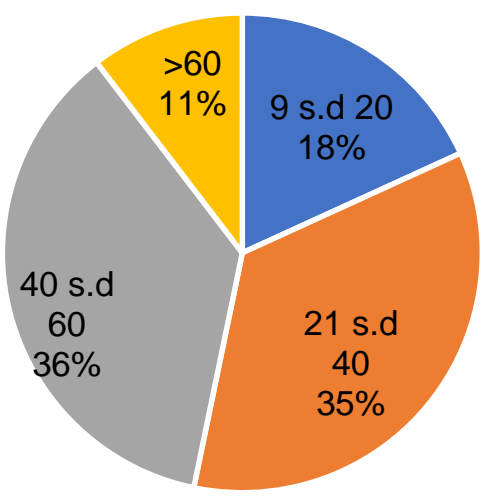

Figure 1. Respondent Age

The education level of the respondents in this study was grouped into SD, SMP, SMA, S1, and $\mathrm{S}_{2} / \mathrm{S}_{3}$. Based on the analysis results, only $1 \%$ of respondents have an elementary school education, the majority of respondents have a high school education $(46 \%), 35 \%$ of respondents have an undergraduate education, and 9\% have a master's or doctoral degree. Education level is known to have an effect on opinions and the ability to answer questionnaires. In addition to analyzing the age and status of education, another variable examined in this study is the respondent's area. The respondents' residences are spread across several urban villages in Medan, such as Namorambe, Medan, Bandar klippa, Deli Tua, Kwala Bekala, Helvetia. The battlefield, Marendal, Stone drying village, Padang Bulan, Ujung Labuhan, Tanjung Sari, Jatikesuma, Labuhan Deli, Namombelin etc. Details of respondents' residences distribution can be seen in Figures 2 (a) and (b).

\subsection{Analysis of Perception}

According to the question "In my opinion, upstream the Deli River is in Deli Serdang district and ends in Medan Belawan" 24\% answer strongly agree, and the majority (56\%) solution agree with the question about Deli River location (Fig. 3(a)). Based on the analysis, most people in Medan believe and know that the headwaters of the Deli River are in Deli Serdang and end up in Medan Belawan, but there are groups of people ( $2 \%$ ) who disagree with the statement. Deli River is a reflection of the civilization of Medan City since the past. The river, formerly known as Sei Deli, is located in the capital city of North Sumatra Province, making this river very successful during the Deli Sultanate. With its 
headwaters in Karo Regency and Deli Serdang Regency, the Deli River flows into the center of Medan City and empties into the Malacca Strait. The Deli River is designated as part of the Belawan-UlarPadang River Area (WS), known as the Watershed (DAS) in the Minister of Public Works and Public Housing Regulation no. 04/PRT/M/2015. The Deli watershed area has 48,162 hectares, with a length of 73 kilometers and a width of 5.58 meters.
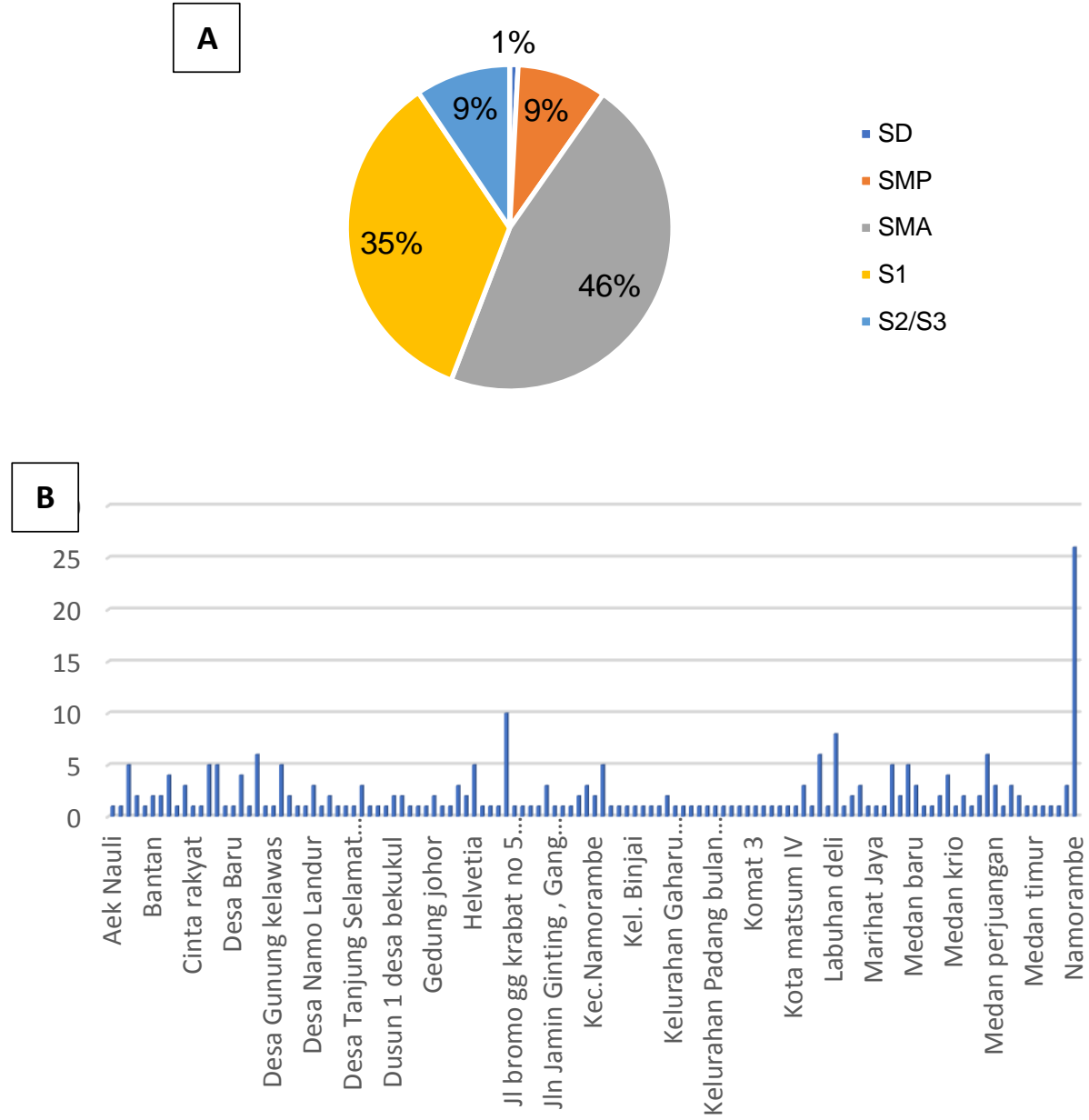

Figure 2. Respondent's level of education (a) and living place (b)

According to the question, "In my opinion, upstream of the Deli River, the water is still clear, clean and not much waste," the majority of Medan residents are strongly disagreeing. Most people in Medan disagree with this statement because the Deli River's physical characteristics have been polluted. The color of the deli river has changed to brown; there is a lot of waste and bad smells along the Deli River of Medan. In addition to waste, the sanitation conditions of the community along the Deli River do not meet the standards, so people still find people who defecate in the Deli River (Fig. 3(b)). A previous study reported that a hundred percent of people around the Deli River using surface water from Deli River for the basic needed and more than $67 \%$ using low distance from the pollutant source $(<10 \mathrm{~m})$, and more than $42 \%$ of people does not have a standard sanitation and toilet facilities (Angeline et al., 2012). Surface water quality is one of the most widely discussed issues in various journals nationally and internationally, with a high reputation. The negative impacts caused by surface water pollution can have a very long effect and require high costs and a long time to recover surface water pollution. High pollution levels will disturb the balance of the ecosystem and kill the diversity of animals and plants in surface water areas. The Deli Medan River is one of the rivers that has been reported to be polluted. A study said that the Deli Medan River in the middle and downstream has a higher $\mathrm{Pb}$ content. The study also noted that the $\mathrm{Pb}$ content in the Deli Medan River was still below the 
environmental quality standard based on Presidential Regulation no. 82 the Year 2001 (Afrianti and Irni, 2019). Although the $\mathrm{Pb}$ content is still below the environmental quality standard, other studies have informed that the Deli Medan River has a high BOD and COD content upstream, middle, and downstream. BOD and COD content in the upstream, middle, and downstream of the Deli Medan River can be seen in Table 1. The impact of high levels of COD causes the absence of aquatic biota life, and the effect of BOD levels is the death of marine life. BOD is a characteristic that indicates the amount of dissolved oxygen required by microorganisms (usually bacteria) to decompose or decompose organic matter under aerobic conditions, and COD is the amount of oxygen needed to break down all organic matter contained in water

Table 1. BOD and COD levels in The Deli Medan River

\begin{tabular}{lcccc}
\hline Segment & $\begin{array}{c}\text { BOD } \\
(\mathbf{m g} / \mathbf{L})\end{array}$ & $\begin{array}{c}\text { COD } \\
(\mathbf{m g} / \mathbf{L})\end{array}$ & $\begin{array}{c}\text { Indonesian National } \\
\text { Standard of BOD } \\
(\mathbf{m g} / \mathbf{L})\end{array}$ & $\begin{array}{c}\text { Indonesian National } \\
\text { Standard of COD }(\mathbf{m g} / \mathbf{L})\end{array}$ \\
\hline Upstream & 2.3 & 13.26 & 2 & 10 \\
Middle & 6.2 & 37.92 & 2 & 10 \\
Downstream & 5.5 & 31.23 & 2 & 10 \\
\hline
\end{tabular}

Source: (Mirandha et al., 2021)
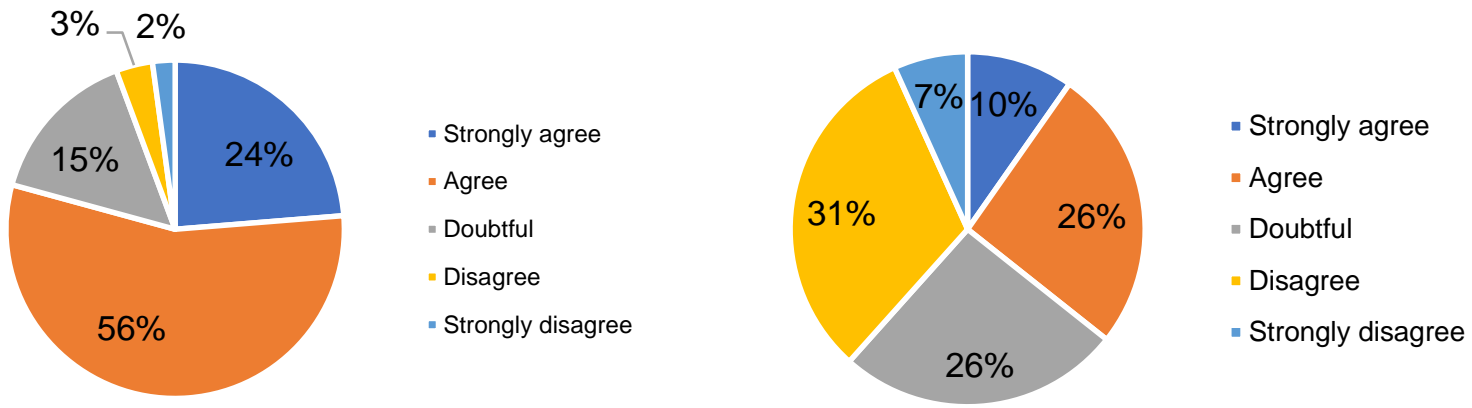

Figure 3. Perception of upstream and ends of Deli River location (a) and Perception of Deli River was polluted (b)

According to the Medan residents, the Deli Medan River was a transportation medium. According to the question "In my opinion, the existence of the Deli River in ancient times was a transportation route for the economy and was traversed by large ships carrying goods?" most people are agreeing (48\%) (Fig. 4(a)). Before the construction of the railway line in the Medan area, the transportation used by the community and industry was ships and other water transportation, but along with the times and the increase in plantation production in the field, transport through the Deli River Medan began to be abandoned and switched to land transportation (Fitri and Indira, 2020). According to the resident perception, the Deli Medan River has been polluting and silting. The silting of the Deli Medan River is one of the causes of flooding both upstream and downstream. Previous research showed that the flood is caused by silting, sedimentation, and people's bad behavior in Medan (Alamsyah, 2018). River siltation occurs due to the deposition of solid particles carried by river currents; these particles can be waste, especially soil particles, due to excessive erosion. This result informed that $36 \%$ of people strongly agree, and $45 \%$ agree that the Deli Medan River has been silting and polluting. The flood disaster that occurred in the city of Medan was also related to knowledge about disposing of waste in the Deli Medan watershed area. A study informs that housewife' knowledge about the benefits 
of managing waste is in the medium category $(57.6 \%)$. As a result of disposing of terrible waste $(47.5 \%)$ and prevention of risk due to debris is also wrong $(45.5 \%)$, housewife misbehave by throwing waste indiscriminately with the potential for flooding in the Deli watershed (72.7\%) (Silalahi, 2017).
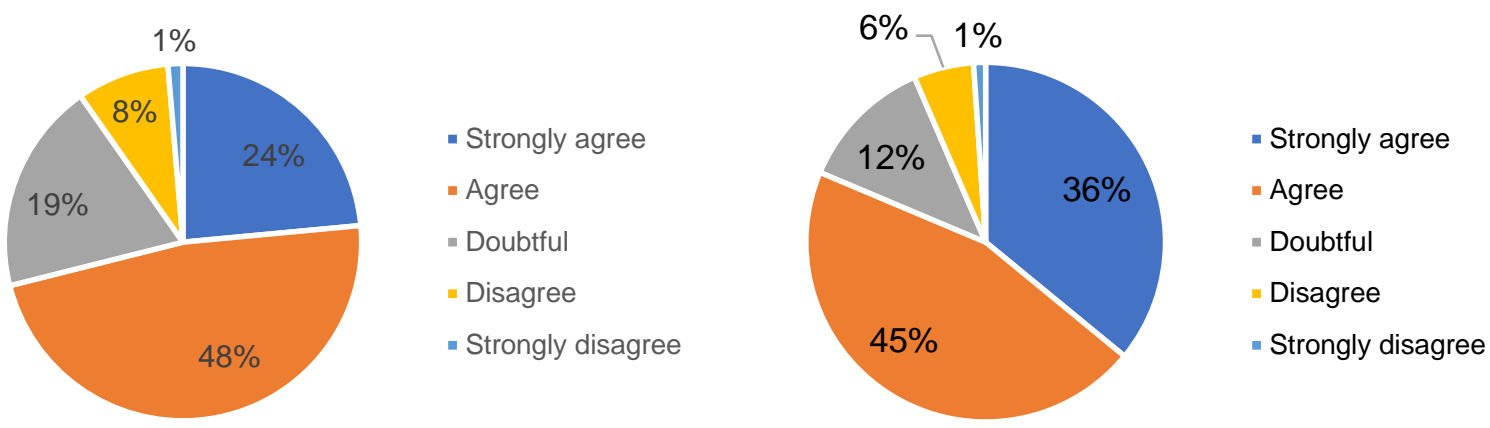

Figure 4. Deli Medan River is a transportation media (a) and river pollution and silting (b)

\subsection{Statistical Analysis}

Analysis of the relationship between the level of pollution in headwaters (Variable 1) and the silting phenomenon in the river body (Variable 2) of the Deli Medan River stated no correlation. This is known based on the significant value of the Spearman correlation test results, which show a significance value of 0.084 (> 0.05). This study informed that silting in the Deli Medan River does not cause headwaters activities (See Table 2). The silting and pollution of the Deli Medan River are caused by waste and industrial activities. A previous study informed that the silting of the Deli Medan River is caused by silt and sedimentation. Silting of the Deli Medan River has been reporting since 1915 (Hutagaol, 2016). The phenomenon of pollution and siltation in the Deli River Medan has no significant relationship with the upstream Deli Medan River; this phenomenon is different from the study conducted in the Siangker River Semarang. The research informs that there is a significant relationship between siltation and heavy metal pollution (Di and Siangker, 2016)

Table 2. The correlation between the level of pollution and the silting of the Deli Medan River

\begin{tabular}{llr|r} 
& & \multicolumn{1}{r}{ VAR00001 } & VAR00002 \\
\hline VAR00001 & Pearson Correlation & 1 & .090 \\
\cline { 2 - 4 } & Sig. (2-tailed) & & .084 \\
\cline { 2 - 4 } & $\mathrm{N}$ & 370 & 369 \\
\hline VAR00002 & Pearson Correlation & .090 & 1 \\
\cline { 2 - 4 } & Sig. (2-tailed) & .084 & \\
\cline { 2 - 4 } & $\mathrm{N}$ & 369 & 370 \\
\hline
\end{tabular}

The correlation between Deli Medan River cannot be a transportation media with the silting and sedimentation showed a strong correlation. The significant value is indicated in the correlation between ship transportation and silting in the Deli Medan River. The sig value is less than o.05 (Table 3). Historical evidence proves that since 1915 there has been siltation of the Deli Medan River not passed by plantation ships. This condition causes the construction of railroads and shifts the mode of transportation from rivers to land. Silting of the river will cause the ship's propeller not to work so that it is not practical to use the river path.

Table 3. The correlation between ship transportation and silting

\begin{tabular}{lll|l} 
& & VAR00005 & VAR00006 \\
\hline VAR00005 & Pearson Correlation & 1 & $.283^{* *}$ \\
\cline { 2 - 3 }
\end{tabular}




\begin{tabular}{lll|l}
\hline & \multicolumn{2}{l}{ Sig. (2-tailed) } & .000 \\
\cline { 2 - 4 } & $\mathrm{N}$ & 370 & 369 \\
\hline \multirow{2}{*}{ VAR00006 } & Pearson Correlation & $.283^{* *}$ & 1 \\
\cline { 2 - 4 } & Sig. (2-tailed) & .000 & \\
\cline { 2 - 4 } & $\mathrm{N}$ & 369 & 370 \\
\hline${ }^{* *}$. Correlation is significant at the 0.01 level (2-tailed).
\end{tabular}

There is a significant relationship between education and public awareness in disposing of waste in the river (See Table 4). The Spearman correlation test analysis results show that the significance value is $<0.05$, which means that education and awareness in disposing of the waste are correlated. The results of this study are in line with previous research that has been carried out on the Musi River Palembang; the results of this study inform that there is a relationship between the level of formal education and public awareness in disposing of waste in the river (Ervina Mukaromah et al., 2020). Although previous research reported that does not show a correlation between formal education, age, and gender with public awareness in disposing of waste in the river (Isthofiyani et al., 2016), another research also reported that do not correlation between public awareness in solid waste management (Eldo Rado Silaban Puji Hardati, 2018). Thus, the correlation between general behavior and formal education levels is not the same.

Table 4. Level of Education and Awareness of Disposing of Waste

\begin{tabular}{llr|r} 
& & VAR00001 & \multicolumn{1}{r}{ VAR00002 } \\
\hline VAR00001 & Pearson Correlation & 1 & $.196^{* *}$ \\
\cline { 2 - 4 } & Sig. (2-tailed) & & .000 \\
\cline { 2 - 4 } & $\mathrm{N}$ & 377 & 376 \\
\hline VAR00002 & Pearson Correlation & $.196^{* *}$ & 1 \\
\cline { 2 - 4 } & Sig. (2-tailed) & .000 & \\
\cline { 2 - 4 } & $\mathrm{N}$ & 376 & 376 \\
\hline
\end{tabular}

${ }^{\star *}$. Correlation is significant at the 0.01 level (2-tailed).

The correlation between the amount of liquid waste discharged by industry and household waste to the current pollution in the Deli River, Medan, is positively correlated (see Table 5). This informs that the degradation in the Deli River Medan is caused by industrial wastewater disposal that is not managed correctly and the disposal of household waste into the Deli River of Medan. Furthermore, the Spearman correlation test results show a significance value below 0.05 , which means variables one and two are correlated.

Table 5. Deli Medan River Pollution and the amount of liquid waste disposal into river bodies

\begin{tabular}{llr|r} 
& \multicolumn{1}{l}{ VAR00001 } & \multicolumn{1}{c}{ VAR00002 } \\
\hline VAR00001 & Pearson Correlation & 1 & $.683^{* *}$ \\
\cline { 2 - 4 } & Sig. (2-tailed) & & .000 \\
\cline { 2 - 4 } VAR00002 & $\mathrm{N}$ & 371 & 371 \\
\cline { 2 - 4 } & Pearson Correlation & $.683^{* *}$ & 1 \\
\cline { 2 - 4 } & Sig. (2-tailed) & .000 & \\
\cline { 2 - 4 } & $\mathrm{N}$ & 371 & 371 \\
\hline${ }^{* *}$. Correlation is significant at the 0.01 level (2-tailed).
\end{tabular}

Other studies also reported the pollution parameters (physical characteristics) of the quality of the Deli Medan River, including temperature, $\mathrm{pH}$, depth, and light intensity. Details of the physical attributes of the Deli Medan River can be seen in Table 6. The test results show that the $\mathrm{pH}$ value of the water is still below the environmental quality standard (6-9); this informs that the water quality of the 
Deli Medan River has been polluted based on the $\mathrm{pH}$ acidity level. The acidic nature of water will negatively impact microorganisms, plants, animals, and humans who use the water of the Deli Medan River to meet their daily water needs. The water temperature is still at the environmental quality standard because it is not too hot or cold. DO is the amount of dissolved oxygen in the water from photosynthesis and absorption of the atmosphere/air; the maximum DO level in river water is three. Based on the test results, the DO value is above the environmental quality standard to harm the lives of animals, plants, and microorganisms in the Deli River Medan. Furthermore, the BOD content in the Deli Medan River is still below the environmental quality standard; the standard BOD value for the river is six, while in some areas, the BOD value is still in the range of 2-4. The intensity and penetration of light serve as tools to assist in providing lighting when catching fish. The river's depth has also varied from 0.9-1.4 m; silting occurs due to mud, solid waste dumped into the river, various industrial wastes, and erosion that continues to occur. River flow velocity is still at normal range (1.6-5.9 m/s)

Table 6. Physical parameters of Deli Medan River

\begin{tabular}{|c|c|c|c|c|c|c|}
\hline No & Parameter & $\begin{array}{c}\text { Salam Tani } \\
\text { Village }\end{array}$ & $\begin{array}{c}\text { Sunggal } \\
\text { Kanan } \\
\text { Village }\end{array}$ & $\begin{array}{c}\text { Kampung } \\
\text { Lalang }\end{array}$ & $\begin{array}{c}\text { Kelambir } 5 \\
\text { Village }\end{array}$ & $\begin{array}{c}\text { Sicanang } \\
\text { Village }\end{array}$ \\
\hline 1 & $\mathrm{pH}$ & 4.0 & 3.0 & 4.0 & 4.0 & 7.6 \\
\hline 2 & $\begin{array}{l}\text { Temperature } \\
\left({ }^{\circ} \mathrm{C}\right)\end{array}$ & 27 & 28 & 28 & 28 & 30 \\
\hline 3 & DO (mg/L) & $5 \cdot 3$ & $5 \cdot 3$ & $5 \cdot 3$ & $5 \cdot 3$ & $5 \cdot 3$ \\
\hline 4 & $\mathrm{BOD}_{5}(\mathrm{mg} / \mathrm{L})$ & 2.2 & 2.3 & 1.3 & 2.6 & 4.0 \\
\hline 5 & Light intensity & 87 & 33 & 26 & 32 & 51 \\
\hline 6 & Depth (m) & 0.9 & 1.1 & 1.2 & 1.1 & 1.4 \\
\hline 7 & $\begin{array}{l}\text { Flow } \quad \text { Speed } \\
(\mathrm{m} / \mathrm{s})\end{array}$ & 2.7 & $5 \cdot 9$ & 1.7 & 1.6 & 3.6 \\
\hline 8 & $\begin{array}{l}\text { Light } \\
\text { Penetration }\end{array}$ & 331 & 611 & 426 & 435 & 535 \\
\hline
\end{tabular}

Source: (Yeanny et al., 2021)

Another study also reported the mercury content in water and sediments in the Deli River Medan, the mercury content found in the water was $0.00052 \mathrm{mg} / \mathrm{L}$, while the mercury content in the sediment was $0.00088 \mathrm{mg} / \mathrm{L}$ and the mercury content in blood clam, common geloina, and antique ark was 0.00024 , 0.00026 , and $0.00095 \mathrm{mg} / \mathrm{L}$ respectively. Thus, all parts of the river and its living creatures contain mercury below the environmental quality standard (Yeanny and Muthawali, 2018). One effort to see the level of pollution in the river is to measure the presence of phytoplankton in the river, and a report reports that there are several types of phytoplankton in the Deli Medan River, including the genus Sphaeroplea, genus Volvox, Stauroneis, Navicula, and Gyrosigma in huge numbers. A little (Yeanny, 2018). These results also confirm that the Deli Medan River is polluted in the mild category; it is classified based on several types of phytoplankton in the Deli Medan River.

\section{Conclusion}

Deli Medan River is one of the rivers in Medan City and has much historical value. The Deli River in Medan was formerly used as a transportation medium for the community and the plantation industry. Along with the times and the development of land transportation modes carried out by the Government, the function of the Medan Deli River is slowly being forgotten. The construction of the railway in the 1980 os has shifted the operation of the river as a transportation medium. Not infrequently, the younger generation does not know the Deli Medan River's location in detail. Some people do not even know and doubt the Deli Medan River's upstream and downstream regions. This study involved 365 respondents from various urban villages in the Medan City area (136 men and 232 girls). The selected respondents are aged 9-6o years with a vulnerable elementary school to a college education. 
Spearman correlation analysis is used to see the relationship between variables. The results of the study inform that there is no relationship between pollution and siltation that occurs in the Deli River Medan, different products are shown between the changing of river transportation modes to land caused by river silting, the level of education and awareness in disposing of waste, as well as pollution that occurs and industries that dispose of waste. Liquid waste in the Medan Deli River body (Sig. <0.05).

\section{References}

Afrianti, S., Irni, J., 2019. Analisa Tingkat Pencemaran Logam Berat Timbal (Pb) Di Daerah Aliran Sungai Deli Sumatera Utara. Biolink (Jurnal Biologi Lingkungan Industri Kesehatan) 6, 153-161.

Airriess, C., 1995. Port-Centered Transport Development in Colonial North Sumatra. JSTOR 59, 65.

Alamsyah, B., 2018. Penanganan problematika banjir di kota Medan berdasarkan pendekatan partisipasi masyarakat. Jurnal Pembangunan Perkotaan 6, 95-101.

Angeline, Y.L., Marsaulina, I., Naria, E., 2012. Hubungan Kondisi Sanitasi Dasar dengan Keluhan Kesehatan Diare serta Kualitas Air pada Pengguna Air Sungai Deli di Kelurahan Sukaraja Kecamatan Medan Mainum Tahun 2012. Jurnal Lingkungan dan Keselamatan Kerja 17, 281-290.

Aulia, F., Harahap, R.H., Absah, Y., 2018. Persepsi Masyarakat Terhadap Keberadaan Sungai Deli di Kota Medan. Jurnal Pembangunan Perkotaan 6, 35-39.

Di, M., Siangker, S., 2016. Hubungan Antara Sedimen dengan Logam Berat dan Makrozoobentos di Sungai Siangker, Semarang. Diponegoro Journal of Maquares 5, 337-344.

Silaban E.R., Hardati P., Hariyanto, 2018. Hubungan Tingkat Pendidikan dan Tingkat Pengetahuan Penduduk terhadap Perilaku Pengelolaan Sampah di Kelurahan Patemon Kecamatan Gunungpati Tahun 2018. Edu Geography 6, 177-181.

Ervina Mukaromah, Handayani, S., Wijayanti, T.F., 2020. Analisis faktor-faktor yang mempengaruhi pola perilaku masyarakat membuang sampah di sungai musi (studi kasus kelurahan 10 ulu). Unbara Environmental Engineering Journal o1, 1-6.

Fadlan, K., Tarigan, A.P.M., Nasution, Z.P., 2021. Penentuan Prioritas Pengelolaan Daerah Aliran Sunga Deli Menggunakan Indeks Potensi Erosi. Syntax Literate Jurnal Ilmiah Indonesia 6, 2265-2279.

Fitri, I., Indira, S.S., 2020. Pengaruh Jaringan Kereta Api Dalam Perkembangan Awal Kota Medan Dan Industri Perkebunan Di Tanah Deli. In: Prosiding Seminar Nasional Pusaka Industri Perkebunan Indonesia. pp. 156-165.

Hutagaol, N.M., 2016. Pengembangan Pelabuhan Belawan Dan Pengaruhnya Terhadap Kehidupan Sosial Ekonomi Masyarakat Deli, 1920-1942. Jurnal Sejarah Citra Lekha 1, 40.

Isthofiyani, S.E., Prasetyo, A.P.B., Retno, S.I., 2016. Persepsi Dan Pola Perilaku Masyarakat Bantaran Sungai Damar Dalam Membuang Sampah Di Sungai. Journal of Innovative Science Education 5, 128-136.

Mirandha, A., Irvan, Wahyuningsih, H., 2021. Spatial distribution of water quality in Belawan River, North Sumatra. IOP Conference Series: Earth \& Environmental Science 713.

Purba, L.W., Naria, E., Cahaya, I., 2013. Hubungan Higiene Pengguna Air Sungai Deli Dengan Keluhan Kesehatan Kulit Dan Tindakan Pencemaran Sungai Di Kelurahan Hamdan Kecamatan Medan Maimun Kota Medan Tahun 2013. Balitbangda Pemko Medan 16, 279-282.

Rachman, I., Dewi F.T., Simanjutak, E., Muklis, Akmal, H., Rambe, R., 2021. Efforts to save the Deli River environment with environmental education for students (study case: schools around the Deli River in Medan City Indonesia). IOP Conference Series: Earth and Environmental Science 802, 012055 .

Silalahi, B., 2017. Pengaruh Pengetahuan tentang Sampah dan Ketersediaan Sarana Prasarana terhadap Perilaku Ibu Membuang Sampah yang Berpotensi Bencana Banjir di Daerah Aliran Sungai Deli Kota Medan. Jurnal Ilmiah Keperawatan Imelda 3, 208-217.

Suprayitno, S., Ratna, R., Ganie, R., Handoko, H., 2020. From Labuhan Deli to Belawan: The Removal of Harbor in Medan during the Dutch Colonial Period of 1863-1942. Budapest International Research 
and Critics Institute: Humanities and Social Research 3, 1392-1402.

Susanti, E., 2018a. Risk Factors of Diarrhea among Communities Living Nearby Deli River Area, North Sumatera. In: The 4th International Conference on Public Health. pp. 42-42.

Susanti, E., 2018b. Risk Factors for Diarrhea Cases in Communities Living Along Deli River, North Sumatera. Journal of Epidemiology and Public Health 04, 47-54.

Yeanny, M.S., 2018. Phytoplankton community as bioindicator of fertility in belawan river. IOP Conference Series: Earth and Environmental Science 130, 012030.

Yeanny, M.S., Barus, T.A., Mawengkang, H., Mulya, M.B., 2021. Analysis of water quality and nutrient content in the Belawan River. IOP Conference Series: Earth and Environmental Science 713, 012059.

Yeanny, M.S., Muthawali, D.I., 2018. Analysis of mercury bioaccumulation on bivalve species in Belawan River. In: Journal of Physics: Conference Series 1116. 052077.

Yunasfi, Desrita, Singh, K.P., 2019. The heavy metal of cuprum $(\mathrm{Cu})$ and lead(Pb) content in Avicennia marina and Rhizophora mucranata. In: IOP Conference Series: Earth and Environmental Science 374, 012064 .

Yusni, E., Melati, P., 2020. Analysis of cadmium (Cd) heavy metal content in Mangrove Crab (Scylla olivacea) meat at Lake Siombak. IOP Conference Series: Earth \& Environmental Science 454, 012123 .

Zandiba Siregar, P., Perwira Mulia Tarigan, A., Irsan, M., Irwandi, H., 2019. GIS-Based Flood Mitigation of Deli River. IOP Conference Series: Material Science \& Engineering 505, 012125.

Zulfa, S., Amsani, H., Zuska, F., 2018. Budaya Pemanfaatan Sungai Deli Sebagai Tempat Pembuangan Limbah Kotoran dan Rumah Tangga Kelurahan Bahari Kota Medan. Jurnal Antropologi Sumatera $16,75-87$. 